\title{
Biometric Study of the Reproductive Organs of Three Breeds of Sheep in Nigeria
}

\author{
Estudio Biométrico de los Órganos Reproductivos de Tres Razas de Ovejas en Nigeria
}

\author{
"Abdullahi Ali Ibrahim; ** Jibril Aliyu; "Rabi Muhammad Ashiru \& **Mustapha Jamilu
}

IBRAHIM, A. A.; ALIYU, J.; ASHIRU, M. \& JAMILU, M. Biometric study of the reproductive organs of three breeds of sheep in Nigeria. Int. J. Morphol., 30(4):1597-1603, 2012.

\begin{abstract}
SUMMARY: A comparative study of testicular biometry was done in rams using three major breeds of sheep in Nigeria. Biometrical parameters observed were scrotal circumference (SC), testes weight (TW), testes length (TL), tunica albuginea weight (TAW), testes volume (TV), testes density (TD), epididymal weight (EW), epididymal length (EL), caput (CA), corpus (CO), cauda weight (CU), epididymal volume (EV) and epididymal density (ED). The results showed significant differences $(\mathrm{p}<0.05)$ between the Uda, Balami and Yankasa breed in the SC, TW, TV, EW, EL, CA, CO, CU, and EV. The Uda had significantly higher $(\mathrm{p}<0.05)$ values in most of the parameters examined than the two other breeds. A bilateral symmetry was observed for Uda and Balami in testes weight and testes volume. It was concluded that the testicular biometry of Uda and Balami observed are suggestive of high spermatozoa per unit mass of the testes and epididymis and subsequently higher fertility, and these biometry can be used by farmers in selecting good breeding animals for genetic improvement.
\end{abstract}

KEY WORDS: Sheep; Testicular; Epididymal; Breeds; Scrotal circumference.

\section{INTRODUCTION}

The indigenous ram in Nigeria belongs to four distinct breeds. The long-legged Sahel (Balami) found in the arid and Sahel region, the Uda popularly known as the black and white or brown and white found in the SudanoSahelian vegitational region, the Yankasa which is the most numerous and widespread found in the guinea savannah and spread to other part of the country, and finally the hardy, short legged West African Dwarf sheep restricted to high altitude areas and humid forest of the south.

Genetic improvement of farm animals may rely on the use of limited number of males either for natural mating or in artificial insemination programmes. However, the growth and development of testicular organs in various species of farm animals has been well documented (Osinowo et al., 1981; Rekwot et al., 1987; Etches, 1996; Oyeyemi \& Ubiogoro, 2005; Bitto \& Egbunike, 2006; Togun \& Egbunike, 2006; Obidi et al., 2008; Ugwu, 2009; Orlu \& Egbunike, 2010). Osinowo et al. (1981) and Togun $\&$ Egbunike reported that testes size is a good indicator of the present and future sperm production in animals. They further observed that the knowledge of basic morphometric characteristics of reproductive organs is of great value inbreeding soundness evaluation and potential fertility in breeding males. Also, Egbunike et al. (1976) reported that morphometric analysis on the testes of any species or breed is necessary in assessing and estimating qualitative changes in testicular components and spermatogenic functions. Similarly, Gage \& Freckleton (2003) further described the mammalian testes as infallible predictors of spermatozoa production. On the other hand, the epididymis is an extremely convoluted structure, which is closely attached to the dorsal part of the lateral surface of the testes (Setchell, 1977; Oyeyemi et al., 2000). Its function includes storage, maturation and absorption of sperm cells.

However, in a bid to increase and improve sheep production in Nigeria, the effect of breed on testicular and epididymal morphometry is essential for a maximum and rational utilization of the breeding stock. Furthermore, there is limited information on a study that compared testicular and epididymal morphometric characteristic of any Nigerian indigenous breeds of sheep. Thus, comparison

\footnotetext{
* Genetics and Animal Breeding Unit, Department of Animal Science, Kano University of Science and Technology, Wudil, Nigeria.

** Genetics and Animal Breeding Unit, Department of Animal Science, University of Maiduguri, Nigeria.
} 
of testicular and epididymal dimensions in the testes of ram from breeds of three markedly divergent origin may provide an insight for studying mechanism controlling ram reproductive capacity. In the report of Siddiqui et al. (2005), reproductive performance depends upon the normal structure and functions of genital organs of an animal. The present study was therefore design to determine and compare the testicular and epididymal morphometry of three breeds of sheep under semi-arid condition.

\section{MATERIAL AND METHOD}

Sample collection. Reproductive tracts of 23 matured rams (5 Balami, 7 Uda and 11 Yankasa) were obtained intoto after slaughter during the Eid-Kabir Sallah period from various household within the Kano city. Collections were done between 0930 and 1200 hours on 2 separate days. The reproductive tracts were immediately brought to the laboratory covered in ice and were processed on the same day.

Testicular morphometry. Scrotal Circumference was evaluated using a piece of thread placed at the greatest diameter and measured on a rule as reported by Osinowo et al. (1981). All weighing of samples was done using a highly sensitive balance in the laboratory.

Paired testes weight and epididymal weight. The testes and epididymis was separated free of adhering connective tissues and fats. The left and right testes and epididymis were measured separately and their weight recorded. The epididymis was then divided into caput, corpus and cauda segment. All the segments were measured for both weight and length.

Testes and Epididymal volume. The volume of the testes and epididymis were measured volumetrically using the Archimedes principles of water displacement in a measuring cylinder and result recorded.

Testes density. The tested density was calculated from the testes and volume and expressed as g cc-1: Testes density $=$ Testes weight $(\mathrm{g}) /$ Testes volume $(\mathrm{cc})$

Tunica albuginae weight. The tunica albuginae was then peeled off each testis after cutting the testes in halves and the weight value recorded.

Statistical analysis. Data collected were subjected to student $\mathrm{t}$-test and the one way analysis of variance (ANOVA) and correlation analysis (Steel \& Torry, 1996).
The statistical model used was

Yijk $=\mu+\mathrm{Gi}+$ eijk; Where Yijk= Observed value per bird, $\mu=$ Fixed overall mean; $\mathrm{Gi}=$ The main effect of Breed $(i=1, . ., 3)$ and eijk= Random error term.

\section{RESULTS}

Table I shows testicular and epididymal measurements of Nigerian rams in respect to breeds. The results of the study revealed that mean scrotal circumference, paired testes weight, mean testes length, paired tunica albuginea weight, mean testes volume, mean testes density, paired epididymal weight, mean epididymal length, caput, corpus, cauda weight, epididymal volume and epididymal density were $34.83 \pm 3.44$, $312.17 \pm 33.96,12.51 \pm 1.01,14.87 \pm 1.03,152.42 \pm 15.48$, $1.01 \pm 0.23,39.65 \pm 9.93,23.17 \pm 2.70,16.61 \pm 3.95,5.29 \pm$ $1.58,18.85 \pm 4.61,19.96 \pm 5.21$ and $1.01 \pm 0.09$ respectively.

The comparison of the morphometric values of the reproductive organs in the three breeds Balami, Uda and Yankasa shows significant differences $(\mathrm{p}<0.05, \mathrm{p}<0.01)$ in scrotal circumference, paired testes weight, mean testes volume, paired epididymal weight, mean epididymal length, and mean epididymal volume (Table I). The Uda has a significantly higher values $(\mathrm{p}<0.05)$ on most of the parameters measured, followed by the Balami and the Yankasa.

Non significant breed differences $(\mathrm{p}<0.05)$ were observed in the biometrical values of testes length, paired tunica albuginea weight, mean testes and epididymal density. All the derivations from the morphometric characteristics measured were unaffected by breeds $(\mathrm{p}<0.05)$ (Table II). However, there was a significant $(\mathrm{p}<0.05)$ difference in the ratio of left to right testes weight (Table II).

The result in Table III, showed that the testes weight had a highly significant correlation with epididymal weight $(\mathrm{r}=0.919, \mathrm{p}<0.01)$, tunica albuginea $(\mathrm{r}=0.958, \mathrm{p}<0.01)$, testes volume $(r=0.998, p<0.001)$, caput weight $(r=0.882$, $\mathrm{p}<0.05)$, corpus weight $(\mathrm{r}=0.861, \mathrm{p}<0.05)$, cauda weight $(\mathrm{r}$ $=0.965, \mathrm{p}<0.001)$, epididymal volume $(\mathrm{r}=0.993, \mathrm{p}<0.001)$ and testes length $(\mathrm{r}=0.818, \mathrm{p}<0.05)$, except the testes density and epididymal density which was negatively correlated with all the morphometric characteristics. There were also positive correlations between testes weight and scrotal circumference $(\mathrm{r}=0.932, \mathrm{p}<0.05)$, and between testicular circumference and epididymal weight $(r=0.932, p<0.05)$, tunica albuginea weight $(r=0.941, p<0.01)$, mean testes volume $(r=0.928$, $\mathrm{p}<0.05)$, caput weight $(\mathrm{r}=0.821, \mathrm{p}<0.05)$, cauda weight $(\mathrm{r}=$ $0.921, \mathrm{p}<0.05)$ and epididymal volume $(\mathrm{r}=0.941, \mathrm{p}<0.01)$. 
Table I. The Biometric Characteristics of the Testicular and Epididymal Organs of three Breeds of Rams (Mean \pm SD).

\begin{tabular}{lcccc}
\hline Measurements & \multicolumn{3}{c}{ Breeds } \\
\cline { 2 - 5 } & Balami $(\mathbf{n}=\mathbf{5})$ & Uda $(\mathbf{n}=\mathbf{7})$ & Yankasa $(\mathbf{n}=\mathbf{1 1})$ & Overall Mean $(\mathbf{S D})$ \\
\hline Scrotal circumference $(\mathbf{c m})$ & $31.25 \pm 3.18^{\mathrm{b}}$ & $38.00 \pm 0.00^{\mathrm{a}}$ & $35.25 \pm 1.77^{\mathrm{b}}$ & $34.83 \pm 3.44$ \\
Paired testes weight $(\mathbf{g})$ & $318.83 \pm 43.18^{\mathrm{a}}$ & $362.28 \pm 32.09 \mathrm{a}$ & $262.41 \pm 33.27 \mathrm{~b}$ & $312.17 \pm 33.96$ \\
Mean testes length $(\mathbf{c m})$ & $12.63 \pm 1.59$ & $12.75 \pm 1.06$ & $12.25 \pm 0.35$ & $12.51 \pm 1.01$ \\
Paired tunic albuginea weight $(\mathbf{g})$ & $14.14 \pm 2.82$ & $16.19 \pm 0.32$ & $12.27 \pm 0.04$ & $14.87 \pm 1.03$ \\
Mean testes volume $(\mathbf{m l})$ & $153.25 \pm 19.85^{\mathrm{a}}$ & $171.50 \pm 12.02^{\mathrm{a}}$ & $130.50 \pm 13.43 \mathrm{~b}$ & $152.42 \pm 15.48$ \\
Mean testes density $\left(\mathbf{g} / \mathbf{c m}^{\mathbf{3}}\right)$ & $1.03 \pm 0.03$ & $1.00 \pm 0.01$ & $1.01 \pm 0.02$ & $1.01 \pm 0.23$ \\
Paired epididymal weight $(\mathbf{g})$ & $36.80 \pm 0.47_{\mathrm{ab}}$ & $51.30 \pm 0.56^{\mathrm{a}}$ & $30.86 \pm 7.07^{\mathrm{b}}$ & $39.65 \pm 9.93$ \\
Mean epididymal length $(\mathbf{c m})$ & $22.12 \pm 3.36 \mathrm{~b}$ & $26.00 \pm 0.71^{\mathrm{a}}$ & $21.37 \pm 0.18^{\mathrm{b}}$ & $23.17 \pm 2.70$ \\
Paired caput weight $(\mathbf{g})$ & $14.06 \pm 2.279^{\mathrm{b}}$ & $21.42 \pm 0.88^{\mathrm{a}}$ & $14.34 \pm 0.10^{\mathrm{b}}$ & $16.61 \pm 3.95$ \\
Paired corpus weight $(\mathbf{g})$ & $4.09 \pm 0.71 \mathrm{~b}$ & $7.14 \pm 1.05^{\mathrm{a}}$ & $4.83 \pm 0.52^{\mathrm{b}}$ & $5.29 \pm 1.58$ \\
Paired cauda weight $(\mathbf{g})$ & $14.36 \pm 4.96^{\mathrm{b}}$ & $23.17 \pm 0.81^{\mathrm{a}}$ & $17.21 \pm 0.43^{\mathrm{b}}$ & $18.85 \pm 4.61$ \\
Mean epididymal volume $(\mathbf{m l})$ & $15.86 \pm 5.46 \mathrm{~b}$ & $25.50 \pm 1.41^{\mathrm{a}}$ & $18.50 \pm 2.12^{\mathrm{b}}$ & $19.96 \pm 5.21$ \\
Mean epididymal density $\left(\mathbf{g} / \mathbf{c m}^{\mathbf{3}}\right)$ & $1.00 \pm 0.14$ & $1.01 \pm 0.07$ & $1.02 \pm 0.13$ & $1.01 \pm 0.09$ \\
\hline
\end{tabular}

Mean on the same row with different superscript differ significantly $(\mathrm{p}<0.05)$.

Table II. Derivations from the morphometric characteristics of the testicular and epididymis of three breeds of sheep (Means \pm SD).

\begin{tabular}{|c|c|c|c|c|}
\hline \multirow[t]{2}{*}{ Parameters } & \multicolumn{4}{|c|}{ Breeds } \\
\hline & Balami $(n=5)$ & Uda $(n=7)$ & Yankasa $(n=11)$ & Overall Mean (StD) \\
\hline $\begin{array}{l}\text { Paired testes weight }(\%) \\
\text { Weight of reproductive tract in toto }\end{array}$ & $71.64 \pm 5.48$ & $72.19 \pm 3.39$ & $72.43 \pm 3.34$ & $72.09 \pm 4.68$ \\
\hline $\begin{array}{l}\text { Paired tunica albuginea weight }(\%) \\
\text { Paired testes weight }\end{array}$ & $4.87 \pm 1.00$ & $4.48 \pm 0.30$ & $4.72 \pm 0.62$ & $4.69 \pm 0.57$ \\
\hline $\begin{array}{l}\text { Paired caput epididymal weight (\%) } \\
\text { Paired testes weight }\end{array}$ & $6.89 \pm 1.97$ & $5.95 \pm 0.77$ & $5.51 \pm 0.65$ & $6.12 \pm 1.18$ \\
\hline $\begin{array}{l}\text { Paired corpus epididymal weight (\%) } \\
\text { Paired testes weight }\end{array}$ & $2.02 \pm 6.02$ & $1.97 \pm 0.12$ & $1.79 \pm 0.42$ & $1.92 \pm 0.36$ \\
\hline $\begin{array}{l}\text { Paired cauda epididymal weight (\%) } \\
\text { Paired testes weight }\end{array}$ & $6.78 \pm 0.93$ & $6.41 \pm 0.35$ & $6.62 \pm 1.00$ & $6.60 \pm 0.65$ \\
\hline $\begin{array}{l}\text { Paired caput epidid ymal weight (\%) } \\
\text { Paired epididymal weight }\end{array}$ & $45.74 \pm 1.43$ & $42.74 \pm 2.68$ & $38.97 \pm 0.76$ & $42.48 \pm 3.34$ \\
\hline $\begin{array}{l}\text { Paired corpus epi didymal weight (\%) } \\
\text { Paired epididy mal weight }\end{array}$ & $13.35 \pm 0.74$ & $13.93 \pm 2.19$ & $12.57 \pm 1.27$ & $13.29 \pm 1.33$ \\
\hline $\begin{array}{l}\text { Paired cauda epididymal weight (\%) } \\
\text { Paired epididymal weight }\end{array}$ & $45.89 \pm 5.56$ & $45.17 \pm 2.07$ & $46.75 \pm 0.58$ & $45.94 \pm 2.76$ \\
\hline & Left : Right & Left : Right & Left : Right & Mean \\
\hline Testes & $100: 94.04 b$ & $100: 90.88^{b}$ & $100: 104.02 \mathrm{a}$ & $100: 96.31$ \\
\hline Epididymis & $100: 96.60$ & $100: 94.61$ & $100: 98.96$ & $100: 96.73$ \\
\hline Tunica albuginea & $100: 93.26$ & $100: 86.36$ & $100: 103.93$ & $100: 94.52$ \\
\hline
\end{tabular}

Mean on the same row with different superscript differ significantly $(\mathrm{p}<0.05)$. 
Table III. Correlations between testicular and epididymal morphometry in three breeds of ram.

\begin{tabular}{|c|c|c|c|c|c|c|c|c|c|c|c|c|c|}
\hline & 1 & 2 & 3 & 4 & 5 & 6 & 7 & 8 & 9 & 0 & 11 & 12 & 13 \\
\hline 1 & - & $0.932^{*}$ & $0.919^{* *}$ & 0.781 & $0.958^{* * *}$ & $0.998^{* * * *}$ & -0.615 & $0.882^{*}$ & $0.861^{*}$ & $0.965^{* * *}$ & $0.993^{* * *}$ & -0.558 & $0.828^{*}$ \\
\hline 2 & & - & $0.932^{*}$ & 0.783 & $0.941^{* *}$ & $0.928^{*}$ & -0.454 & $0.821^{*}$ & 0.776 & $0.921^{*}$ & $0.941^{* *}$ & -0.426 & 0.698 \\
\hline 3 & & & - & 0.766 & $0.989^{* * * *}$ & $0.906^{* * *}$ & -0.521 & $0.968^{* *}$ & $0.926^{*}$ & $0.978^{* *}$ & $0.953^{* *}$ & -0.201 & 0.670 \\
\hline 4 & & & & - & 0.745 & 0.749 & -0.478 & 0.774 & 0.716 & 0.706 & $0.828^{*}$ & -0.430 & 0.362 \\
\hline 5 & & & & & - & $0.952^{* * *}$ & -0.569 & $0.939^{* *}$ & $0.924 * *$ & $0.996^{* * * *}$ & $0.974 * * *$ & -0.301 & 0.762 \\
\hline 6 & & & & & & - & -0.639 & $0.856^{*}$ & $0.857^{*}$ & $0.962^{* *}$ & $0.984^{* *}$ & -0.568 & $0.862^{*}$ \\
\hline 7 & & & & & & & - & -0.447 & -0.775 & -0.589 & -0.594 & 0.300 & -0.747 \\
\hline 8 & & & & & & & & - & $0.894 *$ & $0.947^{* *}$ & $0.923^{* *}$ & -0.204 & 0.577 \\
\hline 9 & & & & & & & & & - & $0.921 *$ & $0.888^{*}$ & -0.148 & 0.577 \\
\hline 10 & & & & & & & & & & - & $0.973^{* *}$ & -0.331 & $0.806^{*}$ \\
\hline 11 & & & & & & & & & & & - & -0.485 & 0.768 \\
\hline 12 & & & & & & & & & & & & - & -0534 \\
\hline 13 & & & & & & & & & & & & & - \\
\hline
\end{tabular}

$*=\mathrm{p}<0.05, * *=\mathrm{p}<0.01, * * *=\mathrm{p}<0.001$. Keys: $1=$ paired testes weight; $2=$ scrotal circumference; $3=$ =paired epididymal weight; $4=$ mean epididymal length; $5=$ paired tunica albuginea weight; $6=$ mean testes volume; $7=$ mean testes density; $8=$ caput weight; $9=$ corpus weight; $10=$ cauda weight; $11=$ mean epididymal volume; $12=$ mean epididymal density; $13=$ mean testes length.

\section{DISCUSSION}

The mean scrotal circumference, paired testes weight and epididymal weight of the three breeds of rams in this study was significantly $(\mathrm{p}<0.05)$ heavier than the $21.50 \pm$ $0.61,134.48 \pm 2.28$ and $19.12 \pm 0.21$ g respectively, reported by Ahemen \& Bitto (2007) for west African dwarf rams. However, our values were generally lower than the values reported by Besta (2006) as testes weight (406 \pm 40 $\mathrm{g})$, testes volume $\left(378 \pm 44 \mathrm{~mm}^{3}\right)$, epididymal weight $(33.85$ $\pm 2.15 \mathrm{~g})$ and epididymal volume $\left(26.67 \pm 3.42 \mathrm{~mm}^{3}\right)$ in Doper rams of South Africa. This differences may be attributed to genotype, as the WAD ram had been described as the smallest breed of indigenous sheep in Nigeria (Osinowo, 1990), while Balami and Uda are believed to be the larger breeds. Similarly, the values for the Doper rams suggest that the breeds are males of larger genotypes found in South Africa.

Scrotal circumference is measured as it gives a good indication of rams breeding ability. Schoenian (2011) reported that ram lamb with scrotal circumference of less than $30 \mathrm{~cm}$ and adult rams with scrotal circumference of less than $32 \mathrm{~cm}$ should probably not be used for breeding. Similarly, Söderquist \& Hultén (2006) reported that for mature rams (17 - 54 months old), the mean scrotal circumference was $34.4 \pm 2 \mathrm{~cm}$ in Gotlandie breed, and $34.5 \pm 0.9 \mathrm{~cm}$ for Dorper ram by Besta. This value supports the results of the present study. From Table 1, it was observed that the scrotal circumference of Uda was significantly $(\mathrm{p}<0.01)$ higher than of the Balami and Yankasa, but there had no significant difference $(\mathrm{p}<0.05)$ between Balami and Yankasa breeds. These differences could be due to the effect of genotype or breed. Similar reports of differences between breeds were earlier reported in goats (Raji et al., 2008) and cattle (Addass, 2011).

Testicular weight, a reliable index of semen producing ability has been shown to vary according to breeds. The Uda and Balami had a significantly $(\mathrm{p}<0.05)$ heavier testes weight than the Yankasa. The two breeds were nearly the same indicating the bilateral symmetry of both testes. The values obtained in this study compares favourably with other breeds of sheep within the tropics and sub-tropics, but much higher than the $134.48 \pm 2.28 \mathrm{~g}$ and $154 \mathrm{~g}$ as reported for WAD rams and Kajli rams in Nigeria and Pakistan by Ahemen \& Bitto and Siddiqui et al. respectively. More so, it was reported that males with larger testes tend to sire daughters that reach puberty at an earlier age and ovulate more ova during each oestrus period (Söderquist \& Hultén). They further reported that testicular weight and size varies with breed, age and time of the season. Although all the animals were fully matured, Abdou et al. (1982) reported that variations in the testes weight are markedly greater between younger bulls and decrease with advancement of age. They further reported that there was evidence that the larger, faster growing bulls would have larger testes than smaller bulls of comparable age. 
It is particularly important to note that in the evaluation of the breeding soundness of an animal, Brito et al. (2004) have reported that heavier testes produce more spermatozoa than the smaller testes. Berdston et al. (1987) asserted that a testis, which possesses greater number of Sustentocytes, were heavier and produced more spermatozoa than testes with fewer Sustentocytes. The significant $(p<0.05)$ higher testes weight of Uda and Balami in this study would mean that those testes could contain more seminiferous tubule, Interstitial endocrine cells, Sustentocytes and possibly more spermatozoa than the Yankasa breeds. More so, the mean testes volume of the Uda and Balami was significantly $(\mathrm{p}<0.05)$ higher than that of the Yankasa breed. The variation in the testes volume for the different breed observed in this study agrees with the report of Ibrahim (2012) in different strains of chicken. De Reviers \& Williams (1984) reported that, among species, due to the larger size of internal and external reproductive organs, larger species consistently produce larger quantities of sperm per ejaculate. This is due to large number of Sustentocytes in the testes, which is related to the capacity for semen production De Reviers \& Williams. The superiority of the Uda and Balami which is believed to be the largest breed of sheep in Nigeria, over their Yankasa and WAD counterparts in this regards is an indication of higher sperm production potentials and a higher storage capacity.

Significant $(\mathrm{p}<0.05)$ breed difference on epididymal weight was evident. Uda had the highest value, followed by the Balami and the Yankasa had the least values. Colyer (1971) reported that the rate of increase in testicular and epididymal weight was linear up to a body weight of 20.9 $\mathrm{kg}$ followed subsequently by a significantly greater rate of increase at higher body weight. He also found close relationship between the development of the testes and the epididymis at the body weight greater than $20.9 \mathrm{~kg}$. However, the significant $(\mathrm{p}<0.05)$ genetic differences observed have suggest breed variability. Other biometric parameters (epididymal length, epididymal volume, caput, corpus and cauda epididymal weight equally shows the superiority of the Uda over the Balami and the Yankasa breed.

The significant difference $(\mathrm{p}<0.05)$ observed in the ratio of left to right testes weight is in strong agreements with the study of Ott et al. (1982) who showed that the left testes was $10 \%$ larger than the right in rams on subsequent examinations. In buffalo, cattle and goats, similar reports have been reported by MacMillan \& Hafs (1969), Ahmad (1984), Ahmad et al. (1985), Purbey \& Choudhury (1985), Ali (1989) and Siddiqui et al.

A significant $(\mathrm{p}<0.05, \mathrm{p}<0.01, \mathrm{p}<0.001)$ and positive correlations exist between the testes weight and all the morphometric characteristics, except the testes and epididymal density. This observation is very much similar with the report obtained in some domestic animals; goat (Bitto \& Egbuinike; Ugwu), ram (Ahemen \& Bitto), domestic chicken (Orlu \& Egbunike; Ibrahim). Similarly, scrotal circumference has been shown to correlates $(\mathrm{p}<0.05$, $\mathrm{p}<0.01)$ with epididymal weight, tunica albuginea, testes volume, and all epididymal segments. Similar observation was reported by Osinowo et al. (1977), Tegegne et al. (1992), Ugwu, Bitto \& Okpale (2006). Overall, the correlation results indicate that the increase in one testicular traits lead to an increase in the other and vice versa. The good and positive correlations between testes weight, scrotal circumference and morphometric characteristics indicates the possibility of predicting organs weight, since testes weight is known to be very highly correlates with testicular sperm reserves (Ogwuegbu et al., 1985) and males with larger testes tend to produce more sperm (Okwun et al., 1996). Also Ugwu asserted that a good measurement of circumference, testes length and width would be a reliable predictor of the sperm producing capacity of bucks. More so, Almquist et al. (1976) and Keith et al. (2009) suggested the use of scrotal size and testicular measurements to select for improved sperm production and breeding males.

\section{CONCLUSION}

From the forgoing therefore, the observation compared results of three breeds of rams in relation to testicular measurements and scrotal circumference. It equally establishes the baseline for the dimensions of different segments of the testicular organs of the Balami, Uda and Yankasa rams in Nigeria. The essential differences between the breeds were the degree to which sperm could be produced. Uda and Balami appeared to be superior to the Yankasa breed. It is concluded that the testicular biometry of Uda and Balami observed are suggestive of high spermatozoa per unit mass of the testes and epididymis and subsequently higher fertility, these breeds can be reliably selected for breeding based on scrotal circumference and testicular biometry. More work on other breeds seems important for better understanding of the reproduction in this animal.

\section{ACKNOWLEDGEMENT}

We are grateful to Professor I.R. Muhammad and Dr M. Kabir of the Departments Animal Science, B.U.K Kano and A.B.U. Zaria respectively, for their technical assistance. 
IBRAHIM, A. A.; ALIYU, J.; ASHIRU, M. \& JAMILU, M.Estudio biométrico de los órganos reproductivos de tres razas de ovejas en nigeria. Int. J. Morphol., 30(4):1597-1603, 2012.

RESUMEN: Se realizó un estudio comparativo de la biometría testicular en carneros con las tres razas principales de ovejas de Nigeria. Los parámetros biométricos observados fueron la circunferencia escrotal (CE), peso testicular (PT), longitud testicular (LT), peso de la túnica albugínea (PTA), volumen testicular (VT), densidad testicular (DT), peso del epidídimo (PE), longitud del epidídimo (EL), peso de la cabeza (CA), cuerpo (CU) y cauda (CA), volumen del epidídimo (VE) y densidad del epidídimo (ED). Los resultados mostraron diferencias significativas $(\mathrm{p}<0,05)$ entre la raza Uda, Balami y Yankasa para la CE, PT, VT, PE, LE, CA, CU, CA, y VE. La raza Uda tuvo valores significativamente mayores $(\mathrm{p}<0,05)$ en la mayoría de los parámetros analizados con las otras dos razas. Se observó una simetría bilateral en el peso de los testículos y el volumen de los testículos para las razas Uda y Balami. Se concluyó que la biometría testicular observada en las razas Uda y Balami son sugerentes de alta cantidad de espermatozoides por unidad de masa de los testículos y el epidídimo, y subsecuentemente una alta fertilidad. La biometría de éstos pueden ser utilizada por los agricultores en la selección de buenos animales para la mejora genética de las crías.

PALABRAS CLAVE: Ovejas; Epidídimo testicular; Razas; Circunferencia escrotal.

\section{REFERENCES}

Abdou, M. S. S.; El Sayed, M. A. I.; Seida, A. A. \& El Wishy, A. B. Gonadal and epididymal sperm numbers in adult buffalo bulls. Vet. Med. J. Giza, 30:327, 1982.

Addass, P. A. Genotype and seasonal variations in testes and paired epididymal sperm production among indigenous bull cattle in Mubi Adamawa State, Nigeria. Agric. Biol. J. N. Am., 2(1):1922, 2011.

Ahmad, M.; Latif, M.; Ahmad, M.; Khan, I. H.; Ahmad, N. \& Anzar, M. Postmortem studies in infertile buffalo bulls. Anatomical and microbiological findings. Vet. Res., 117(5):104-9, 1985.

Ahmad, N. Studies on the postnatal development of the reproductive organs in Nili Ravi buffalo calves. MSc. Thesis, Faisalabad Pakistan, Dept. of Animal Reproduction, University of Agriculture, 1984.

Ahemen, T. \& Bitto, I. I. Sperm production rate, Gonadal and extragonadal sperm reserves of the West African Dwarf rams in Makurdi. March 18-21. Proc. of the 32nd Annu. Conf. of Nig. Soc. for Anim. Prod., 2007. pp.99-101.

Ali. M. Studies on the prepubertal development of the reproductive organs and other related endocrine glands in male Nili Ravi buffalo bull calves of 6 month age. MSc. Thesis, Lahore Pakistan, Dept. of Animal Reproduction, College of Veterinary Science, 1989.

Almquist, J. O.; Branas, R. F. \& Barber, K. A. Postpubertal changes in semen production of Charolaise bulls ejaculated at high frequency and the relation between testicular measurements and sperm output. J. Anim. Sci., 42(3):670-6, 1976.

Berndtson, W. E.; Igbochi, G. \& Pickett, P. W. Relationship between absolute numbers of sertoli cells to testicular size and spermatogenesis in young beef bulls. J. Anim. Sci., 64(1):2416, 1987.
Besta, N. Effect of different dietary energy levels on productive and reproductive traits in Dorper rams. $\mathrm{PhD}$ Thesis, University of the Free State Bloemfontein, 2006.

Bitto, I. I. \& Okpale, M. I. Sperm production rate, Gonadal and extragonadal sperms reserves in slaughtered White Fulani (Bunaji) bulls in a lowland tropical environment. Nig. J. Anim. Prod., 33(2):300-7, 2006.

Bitto, I. I. \& Egbunike, G. N. Seasonal variations in the morphometric characteristics of the pubertal West Africa Dwarf Bucks in its Native Tropical Environment. Int. J. Morphol., 24(4):637-42, 2006.

Brito, I. F. C.; Silva, A. E. D.; Unanian, M. M.; Dode, M. A. N.; Barbos, R. T. \& Kastelic, J. P. Sexual development in early and late maturity Bos Indicus and Bos Indicus X Bos Taurus cross bred bulls in Brazil. Theriogenology. New York, Elsevier Science Inc., 2004. pp.1177-217.

Colyer, R. J. Development of testes and epididymis of Clan forest ram. Department of Gr. Univ. Coll. Wales Abervstwth, 76:43341, 1971.

De Riviers, M. \& Williams, J. B. Testes development and production of spermatozoa in the cockerels (Gallus domesticus). In: Cunningham, F. J.; Lake, P. E. \& Hewitt, D. (Eds.). Reproductive Biology of Poultry. Longman, Harlow, 1984. pp.183-202.

Egbunike, G. N.; Holtz, W. \& Smidt, D. Reproductive capacity of German Landrace boars. II: Sperm production rates as determined by quantitative testicular histology and from gonadal sperm reserves. Zuchthygeine, 11:35-7, 1976.

Etches, R. J. Biotechnology and Genetic Improvement of Poultry. New Delhi, Proceedings of the 11th World's poultry Progress, 1996. pp.295-304. 
Gage, M. J. \& Freckleton, R. P. Relative Testis size and sperm morphometry across mammals: No evidence for an association between sperm competition and sperm length. Proc. Biol. Sci., 270(1515):625-32, 2003.

Ibrahim, A.A. Assessments of the semen quality, testicular development and carcass characteristics of four strains of cockerels in a semi arid environment of Kano State, Nigeria. M.Sc. Thesis. University of Maiduguri, 2012.

Keith, L.; Okere, C.; Solaimam, S. \& Tiller, O. Accuracy of predicting body weights from body conformation and testicular morphometry in pubertal Boer goats. Res. J. Anim. Sci., 3(2):26$31,2009$.

MacMillan, K. I. \& Hafs, H. D. Reproductive tract of Holstein bulls from birth through puberty. J. Anim. Sci., 28(2):233-9, 1969.

Obidi, J. A.; Onyeanusi, B. I.; Ayo, J. O.; Rekwot, P. I. \& Dzenda, T. Determination of gonadal sperm/spermatid reserve in shikabrown breeder cocks. Int. J. Poultry Sci., 7(12):1200-3, 2008.

Ogwuegbu, S. O.; Oko, B. O.; Akusu, M. O. \& Arie, T. A. Gonadal and Extragonadal Sperm Reserves of the Maradi (Red Sokoto) goats. Bull. Anim. Health Prod. Afr., 33:139-41, 1985.

Okwun, O. E.; Igboeli, G.; Ford, J. J.; Lunstra, D. D. \& Johnson, L. Number and function of Sertoli cells, number and yield of spermatogonia, and daily sperm production in three breeds of boar. J. Reprod. Fertil., 107(1):137-49, 1996.

Orlu, E. E. \& Egbunike, G. N. Breed and seasonal Variation in the Testicular Morphometry, Gonadal and Extragonadal Sperm Reserves or Barred Plymouth Rock and Nigerian Indigenous Breeds of the Domestic Fowl. Pak. J. Biol. Sci., 13(3):120-5, 2010

Osinowo, E. O.; Dennis, S. M.; Osori, D. I. K. \& Molokwu, E. C. T. Scrotal and Testicular Dimensions in some West African Bulls. Niger. J. Anim. Prod. 4(2):31-6, 1977.

Osinowo, E. O.; Molokwu, E. C. \& Osori, D. C. Growth and testicular development in Bunaji bulls. J. Anim. Res., 1(1):55-67, 1981.

Osinowo, O.A. Breed selection, reproduction and breed management in the local small ruminant breeds. In: Osinowo, A. O. \& Abatan, A. A. (Eds.). The Nigerian sheep and goat production manual. Zaria, NAPRI Workshop Training, 1990. pp.7-18.

Ott, R. S.; Heath, E. H. \& Bane, A. Abnormal spermatozoa, testicular degeneration, and varicocele in a ram. Am. J. Vet. Res., 43(2):2415,1982 .

Oyeyemi, M. O. \& Ubiogoro, O. Spermiogram and morphological characteristics in testicular and epididymal spermatozoa of large white boar in Nigeria. Int. J. Morphol., 23(3):235-9, 2005.

Oyeyemi, M. O.; Ola-Davies, O. E.; Oke, A. O. \& Idehen, C. Morphological changes in sperm cells during epididymal transit in West African Dwarf Bucks. Tropical Vet., 18:207-12, 2000.
Purbey, L. N. \& Choudhury, N. Biometry of different parts of morbid genitalia in nondescript male buffalos. Indian Vet. Med. J., 9:1215,1985 .

Raji, A. O.; Igwebuike, J. U. \& Aliyu, J. Testicular biometry and its relationship with body weight of indigenous goats in a semi arid region of Nigeria. ARPN Journal of Agriculture and Biological Sciences, 3(4):155-60, 2008.

Rekwot, P. I.; Lamidi, O. S.; Adamu, A. M.; Egbuedo, C. U.; Ruwaan, J. S. \& Okereke, S. N. Reproductive performance of Bunaji bulls grazing natural pasture and receiving supplement containing palm karnel meal. Nig. Vet. J., 18:26-36, 1987.

Schoenian, S. Sheep 201. Bigginers Guide to Raising Sheep. 2011. Available in: http://www.sheep101.info/201/

Setchell, B. P. Male Reproductive Organs and Semen. In: Cole, H. H. \& Cupps, P. T. (Ed.s). Reproduction in Domestic Animals. 3rd ed. New York, Academic Press, 1997. pp.229-53.

Siddiqui, H. U. R.; Ahmad, A. \& Khan, M. Z. Biometrical Studies of Testes of Ram. Short Communication. J. Agri. Soc. Sci., 1(1):789, 2005.

Söderquist, L. \& Hultén, F. Normal values for the scrotal circumference in rams of gotlandic breed. Reprod. Domest. Anim., 41(1):61-2, 2006.

Steel, R. G. D. \& Torry, J. H. Principles and procedures of statistics. A Biometrical Approach. 3rd Ed. New York, McGraw-Hill Book Co. Inc., 1996. p.672.

Tegegne, A.; Entwistle, K. W. \& Mukasa-Mugerwa, F. Genotype differences in Gonadal and extragonadal sperm reserves in mature Zebu bulls in Ethiopia. Anim. Reprod. Sci., 29(3-4):20511, 1992.

Togun, V. A. \& Egbunike, G. N. Seasonal variations in the sperm production characteristics of Zebu (White Fulani) cattle genitalia in the humid tropical environment. Middle-East $J$. Sci. Res., 1(1):87-95, 2006.

Ugwu, S. O. C. Relationship between Scrotal circumferences, in situ Testicular Measurement and Sperm Reserves in the West African Dwarf Bucks. Afr. J. Biotechnol., 8(7):1354-7, 2009.

Correspondence to:

Abdullahi Ali Ibrahim

Genetics and Animal Breeding Unit

Department of Animal Science

Kano University of Science and Technology

Wudil

NIGERIA

Email: talk2aai@yahoo.com

Received : 28-02-2012

Accepted: 30-07-2012 